\title{
Study on the Relationships among Marketing Information System Quality and Brand Equity Management in Banking Sector
}

\author{
Mohamed Salih Yousif Ali* \\ Assistant Professor, Department of Business Administration, College of Science and Humanities Studies, Prince Sattam Bin Abdulaziz \\ University, Al-Aflaj, KSA \\ *E-mail for correspondence: msyali69@yahoo.com \\ Cell Phone: +966559684026
}

\begin{abstract}
Marketing information system plays critical role in improving brand power and long-term profitability. The purpose of this study was to investigate the relationship between marketing information system quality (MKISQ) and brand equity management (BEM) within the banking sector. Results show that the three components of the MKISQ: marketing information quality, marketing support service quality, and marketing orientation quality Influence brand equity. This study contributes to the theoretical and managerial implication empirical of the MKISQ and BEM. The paper provides detail discussion, Imitations and suggestions for future research.
\end{abstract}

Keywords: Marketing system quality, brand equity, Banking Sector

\section{INTRODUCTION}

Information technology is an important tool in attaining the desired growth and competitiveness of today's business. It may also constitute a major share of an organization's capital investment (Alshawi et al., 2003; Kumar, 2004; Huang et al., 2006). The move towards ITbased marketing information systems will improve the quality of internal and external communication flows and facilitate better communication within organizations (Saaksjarvi and Talvinen, 1993). There is ample evidence that it is increasingly important for organizations to make the use of information technology to support marketing management, particularly in competitive or rapidly changing environments (Marshall and LaMotte, 1992). The marketing information system database can be used to segment a company market, to record responses, reactions of customers and prospects to company initiatives (Petrison and Wang, 1993).

The current study uses a sample of marketing managers from Sudanese Banking Sector (SBS) to explain the link between marketing information system quality and brand equity management. This study suggests that marketing information system quality variables (system quality, information quality, support service quality, and marketing orientation quality) influence brand equity management. The following section presents the literature review and research hypotheses.

\section{Literature ReVIEW and Research Hypotheses}

"Brand equity empowers companies to negotiate lower costs of distribution, increased effectiveness in marketing communication, and expanded growth opportunities from brand extensions and licenses" (Yoo and Donthu, 2001). Brand equity is important due to the quality-laden informational content that it provides when consumers process information about a particular product. Also, the importance of brand equity has led to many published studies that explore the importance of brand equity in marketing (Keller, 1993). Branding had been described as "the cornerstone of services marketing for the twenty-first century" (Berry, 2000). "Strong service brand not only serves as a promise of future satisfaction but also increases customer trust associated with the invisible purchase enabling them to visualize and understand intangible products" (Berry, 2000).However, Marconi, (1993) "stressed that brand is not just a name because the name is created to identify the product whereas the brand is created to add value to the product and give it a personality". "The difficult task for marketers is to identify which marketing mix components play a key role in improving value equity, brand equity and relationship equity, while attracting new customers and retaining the existing ones" (Lemon et al., 2001; Hanssens et al., 2008). Brand equity focuses on subjective perceptions such as brand image, brand awareness, and brand ethics (Rust et al., 2000).

As each customer equity components have a different significance level in a certain market, an organization should identify the factors that have the highest effect on customer preferences (i.e. strong brand, product quality and price, valuable long-term relationship) and "to drive its marketing efforts in the right direction" (Lemon et al., 2001). It has also been pointed out that, after spending huge amounts of money on customer relationship 
management technologies, some firms do not know how to manage customer relationships with these new databases, and have therefore achieved negative returns for their investments (Rigby et. al., 2002).

By focusing on marketing's effect on individual customers, rather than the impact of aggregate expenditures, a firm can create a customer-centered approach to brand management (Rust et al., 2004). Maguire and Ojiako, (2008) "study also, re-emphasized the need to ensure that customer and user perceptions were taken into consideration during any project systems introduction". More specifically, marketing information system could contribute to the proper identification of consumer needs and, as a result, help to cultivate a more satisfied and loyal customer (Barcheldor, 1999). Service quality can increase customer loyalty, retention and improved business performance (Ennew and Binks, 1996). Regarding marketing orientation, many researchers stressed its role as "one of the most factor influencing marketing information system usage and effectiveness" (Wierenga and Staelin, 1999). "The adoption of marketing orientation can be facilitates each company's collection, processing and diffusion of information resulting in the company's knowledge of the customer's need" (Kalliopi et al., 2010; Kohli and Jaworski, 1990; Narver and Slater, 1990). Based on the above discussions, the following hypotheses were generated:

Hypothesis 1: $\quad$ There is a positive relationship between marketing system quality and brand equity.

Hypothesis 2: $\quad$ There is a positive relationship between marketing information quality and brand equity.

Hypothesis 3: There is a positive relationship between marketing support service quality and brand equity.

Hypothesis 4: $\quad$ There is a positive relationship between marketing orientation quality and brand equity.

\section{Research Method}

\section{Data and procedures}

To collect the data, the chosen scale items were translated from English into the Arabic language to avoid translation errors and minimize loss or dilution of meaning. Further senior marketers with a good understanding of the aim of the study refined the construct measurements to suit the banking context. To test the clarity and ambiguity in the instrument, a pilot study is administered with 25 senior marketers. The finding of this pre-test was the revisions to some items. All questions are answered on a five-point Likert scale which arranging from strongly agree to strongly disagree.

The survey sample consisted of 160 banking marketing managers in Sudan banking sector, selected by purposive sampling with the final returns yielded 117 usable questionnaires, which constitute a response rate of 73 percent. The questionnaire contains three sections: Section one deals with the respondent's profile, Section two deals with the bank's perception of marketing information system while Section three deals with brand equity.

\section{Measures}

All the measurements of variables that used in this study were drawn from the literature review. System quality is defined interms of accuracy, process speed, quick response time, easy access, easy use, and friendly working environment (DeLone and McLean, 2004). The measurement used the scale included six items employed by (Kalliopi et. al.,2010; Abdel Hafiez and Mohamed, 2014). Information quality is defined as the information that marketing executives need in order to cover their specific needs and their quality, which in turn defines the type of marketing applications executives choose to use it (Wierenga, 1999). Information quality measurement scale included eight items adopted from (Bailey and Pearson, 1983; Abdel Hafiez and Mohamed, 2014).

Marketing orientationis defined as the organization-wide generation of market intelligence and disseminating/ responding to market intelligence across departments in the organization (Jaworski and Kohli, 1993), the chosen measure scale was developed by Narver and Slater (1990), and Kohli and Jaworski (1990). Specifically, the scale included 6 items referring to all six marketing orientation dimensions. Support service quality defined as a fundamental requirement for a successful service business, and a strong predictor of customer perceptions and loyalty (Zeithamlet al.,1996). So support service quality is measured by (Gounaris and Venetis, 2002; Abdel Hafiez and Mohamed, 2014) scale. "Brand equity is defined as the customer's subjective and intangible assessment of brand, above and beyond its objectively perceived value" (Rust et al., 2000).The brand equity measure is adopted from (Rust et al., 2004).

\section{ANALYSIS AND RESULTS}

Descriptive statistics, factor analysis, reliability tests, correlation analysis, and regression analysis was used to analyze the data in this study. Table 1 shows the respondents profile, most of the respondents were male and married with an age 40and less than 50 years; the majority is post graduated with experience of 20 years and more.

Table 1: Respondents Profile

\begin{tabular}{|c|c|c|c|}
\hline Variables & Category & Frequencies & $\%$ \\
\hline \multirow[t]{4}{*}{ Age } & less than 40 & 38 & 32.5 \\
\hline & 40 and less than 50 & 51 & 43.5 \\
\hline & 50 and less than 60 & 28 & 24.0 \\
\hline & Total & 117 & $100 \%$ \\
\hline \multirow[t]{3}{*}{ Gender } & Male & 94 & 80.34 \\
\hline & female & 23 & 19.66 \\
\hline & Total & 117 & $100 \%$ \\
\hline \multirow{4}{*}{$\begin{array}{l}\text { Marital } \\
\text { status }\end{array}$} & single & 18 & 15.4 \\
\hline & married & 96 & 82.0 \\
\hline & others & 3 & 2.6 \\
\hline & Total & 117 & $100 \%$ \\
\hline \multirow{4}{*}{$\begin{array}{c}\text { Educational } \\
\text { level }\end{array}$} & secondary & 2 & 1.71 \\
\hline & graduate & 44 & 37.61 \\
\hline & postgraduate & 71 & 60.68 \\
\hline & Total & 117 & $100 \%$ \\
\hline \multirow[t]{2}{*}{ Experience } & 10 and less than 15 year & 30 & 25.64 \\
\hline & 15 and less than 20 year & 34 & 29.06 \\
\hline
\end{tabular}




\begin{tabular}{|c|c|c|c|}
\hline & 20 years and more & 53 & 45.30 \\
\cline { 2 - 3 } & Total & 117 & $100 \%$ \\
\hline
\end{tabular}

\section{Goodness of Measures}

To ensure the goodness of measures, Factor Analysis is conducted, following the assumptions recommended by (Hairet al., 2010). Firstly, there must be a sufficient number of statistically significant correlations in the matrix. Secondly, Kaiser-Meyer-Olkin measure of sampling adequacy should be at least 0.6. Thirdly, Bartlett's test of sphere-city should be significant at 0.05. Fourthly, communalities of items should be greater than 0.50. Fifth, the minimum requirement of factor loading should be 0.50 based on a 0.05 level of significant, with value of cross loading exceeds 0.50. Also to provide a simple structure column for interpretation, the factors are subjected to varimax rotation. Finally, Eigen values should be more than one for factor analysis extraction.

Factor analysis is done on the statements that are used to measure marketing information system quality constructs and brand equity. Tables (2 to 6) show the results summary of the factor analyzes as the following:

\section{Factor Analysis for marketing system quality:}

Factor analysis is done on six statements, which was used to measure System Quality (SYQ). Table (2) shows the summary of results of factor analysis on the system quality. In the first run of factor analysis, statementsSYQ4 and SYQ6 were found to have communalities less than 0.50, statement SYQ4 is dropped. In the second run also the statement SYQ6 was found to have communalities less than 0.50, statement SYQ6 is dropped in the subsequent run. Also to provide a simple structure column for interpretation, the factors were subjected to Varimax rotation. Remaining the statements had more than recommended value of at least 0.50 in MSA with KMO value of 0.91 (above the recommended minimum level of 0.60 ), and Bartlett's test of sphericity is significant (279.841, $\mathrm{p}<.01)$. Finally, all assumptions were satisfactorily fulfilled.

Table 2: Factor Analysis for marketing system quality

\begin{tabular}{|l|c|c|c|}
\hline \multicolumn{1}{|c|}{ Statement } & \multicolumn{2}{c|}{ Communalities } & Componen \\
\cline { 2 - 3 } & Initial & Extraction & Matrix \\
\hline $\begin{array}{l}\text { SYQ2 The bank system is } \\
\text { efficient }\end{array}$ & 1 & .863 & .929 \\
\hline $\begin{array}{l}\text { SYQ1 The bank system } \\
\text { provides accurate } \\
\text { information }\end{array}$ & 1 & .783 & .885 \\
\hline $\begin{array}{l}\text { SYQ3 The bank system has } \\
\text { quick response time }\end{array}$ & 1 & .679 & .824 \\
\hline $\begin{array}{l}\text { SYQ5 The bank system has } \\
\text { easy use }\end{array}$ & 1 & .679 & .824 \\
\hline Kaiser-Meyer-Olkin Measure of Sampling Adequacy & .787 \\
\hline Bartlett's Test of Sphericity Approx. Chi-Square & 279.841 \\
\hline df & 6 \\
\hline Sig & .000 \\
\hline Initial Eiganvalues & 3.003 \\
\hline Total Variance Explained\% & $75.08 \%$ \\
\hline
\end{tabular}

Note: Variables loaded significantly on factor with Coefficient of at least $0.5, \mathrm{~N}=117,{ }^{* *} \mathrm{p}<0.01$

Table 2 also shows that the statements for system quality loaded on one factor with Eigen values exceeding 1.0.
This factor explains $75.08 \%$ of the variance in the data, and the factor loading of system quality statements ranged from 0.787 to 0.929 . Thus, the statements are appropriate for factor analysis, and this study found that system quality consists of four items.

\section{Factor Analysis for marketing information quality:}

Factor analysis is also done on eight statements, which was used to measure Information Quality (INQ). Table (3) shows the summary of results of factor analysis on information quality. In the first run of factor analysis, statement INQ7 was shown to have communalities less than 0.50, and it is dropped before the second run. Also to provide a simple structure column for interpretation, the factors were subjected to Varimax rotation. In the second run all the items had more than recommended value of at least 0.50 in MSA with KMO value of 0.91 and Bartlett's test of sphericity is significant (599.549, $\mathrm{p}<.01)$. Finally, all assumptions were satisfactorily fulfilled. Table (3) also shows that the statements for information quality loaded on one factor with Eigen values exceeding 1.0. This factor explains $72.04 \%$ of the variance in the data, and the factor loading of information quality statements ranged from 0.820 to 0.879. Thus, the statements are appropriate for factor analysis, and this study found that information quality consists of seven items.

Table 3: Factor Analysis for marketing information quality

\begin{tabular}{|l|c|c|c|}
\hline \multirow{2}{*}{ Statement } & \multicolumn{2}{|c|}{ Commulities } & Compone \\
\cline { 2 - 4 } & Initial & $\begin{array}{c}\text { Extracti } \\
\text { on }\end{array}$ & nt Matrix \\
\hline $\begin{array}{l}\text { INQ6The bank information has } \\
\text { completeness }\end{array}$ & 1 & .773 & .879 \\
\hline $\begin{array}{l}\text { INQ5 The bank information has } \\
\text { precision }\end{array}$ & 1 & .729 & .854 \\
\hline INQ1 The bank information is clear & 1 & .728 & .853 \\
\hline $\begin{array}{l}\text { INQ4 The bank information has } \\
\text { timeliness }\end{array}$ & 1 & .720 & .849 \\
\hline $\begin{array}{l}\text { INQ8 The bank information has } \\
\text { reliable and relevance }\end{array}$ & 1 & .717 & .847 \\
\hline INQ3 The bank information is up to date & 1 & .702 & .838 \\
\hline INQ2 The bank information has format & 1 & .673 & .820 \\
\hline Kaiser-Meyer-Olkin Measure of Sampling Adequacy & .914 \\
\hline Bartlett's Test of Sphericity Approx. Chi-Square & 599.549 \\
\hline df & 21 \\
\hline Sig & .000 \\
\hline Initial Eiganvalues & 5.043 \\
\hline Total Variance Explained\% & $72.04 \%$ \\
\hline
\end{tabular}

Note: Variables loaded significantly on factor with Coefficient of at least $0.5, \mathrm{~N}=117,{ }^{* *} \mathrm{p}<0.01$

\section{Factor Analysis for marketing support service quality:}

Factor analysis is done on seven statements, which was used to measure Support Service Quality (SSQ). Table (4) shows the summary of results of factor analysis on support service quality. In the first run of factor analysis, statements SSQ6 and SSQ4 were shown to have communalities less than 0.50, statement SSQ6 is dropped before run two. In the second run also statement SSQ4 
was found to have communalities less than 0.50, statement SSQ4 is dropped. Also to provide a simple structure column for interpretation, the factors were subjected to Varimax rotation.The other items had more than recommended value of at least 0.50 in MSA with $\mathrm{KMO}$ value of 0.82 and Bartlett's test of sphericity is significant $(\mathrm{p}<.01)$. Finally, all assumptions were satisfactorily fulfilled. Table (4) also shows that the statements for support service quality loaded on one factor with Eigenvalues exceeding 1.0. This factor explains $61.51 \%$ of the variance in the data, and the factor loading of support service quality statements ranged from 0.709 to 0.846 . Thus, the statements are appropriate for factor analysis, and this study found that support service quality consists of five items.

Table 4: Factor Analysis for support service quality

\begin{tabular}{|l|c|c|c|}
\hline Statement: At my bank & \multicolumn{2}{|c|}{ Communalities } & Compone \\
\cline { 2 - 3 } & Initial & Extraction & nt Matrix \\
\hline $\begin{array}{l}\text { SSQ5 Performance rewards gives } \\
\text { directions to workforce }\end{array}$ & 1 & .715 & .846 \\
\hline $\begin{array}{l}\text { SSQ7 service oriented culture } \\
\text { enhances the service quality }\end{array}$ & 1 & .637 & .798 \\
\hline $\begin{array}{l}\text { SSQ3 Teamwork is often seen as a } \\
\text { means of supporting willingness } \\
\text { to deliver service quality }\end{array}$ & 1 & .620 & .788 \\
\hline $\begin{array}{l}\text { SSQ1 recruitment is for the best } \\
\text { possible personnel }\end{array}$ & 1 & .600 & .774 \\
\hline $\begin{array}{l}\text { SSQ2 training is claimed to be one } \\
\text { of the essential features for } \\
\text { improving quality }\end{array}$ & 1 & .503 & .709 \\
\hline Kaiser-Meyer-Olkin Measure of Sampling Adequacy & .823 \\
\hline Bartlett's Test of Sphericity Approx. Chi-Square & 218.213 \\
\hline df & 10 \\
\hline Sig & .000 \\
\hline Initial Eiganvalues & 3.076 \\
\hline Total Variance Explained\% & $61.51 \%$ \\
\hline
\end{tabular}

Note: Variables loaded significantly on factor with Coefficient of at least $0.5, \mathrm{~N}=117,{ }^{* *} \mathrm{p}<0.01$

\section{Factor Analysis for marketing orientation quality:}

Factor analysis is done on six statements, which was used to measure Marketing Orientation Quality (MOQ). Table (5) shows the summary of results of factor analysis on marketing orientation quality. In the first run of factor analysis, all the statements were shown to have communalities above than 0.50 . Also to provide a simple structure column for interpretation, the factors were subjected to Varimax rotation. All the remaining statements had more than recommended value of at least 0.50 in MSA with KMO value of 0.86 and Bartlett's test of sphericity is significant $(675.482, \mathrm{p}<.01)$. Finally, all assumptions were satisfactorily fulfilled. Table (5) also shows that the statements for marketing orientation quality loaded on one factor with Eigen values exceeding 1.0. This factor explains $73.76 \%$ of the variance in the data, and the factor loading of marketing orientation quality statements ranged from 0.713 to 0.923 . Thus, the statements are appropriate for factor analysis, and this study also found that marketing orientation quality consists of six items.
Table 5: Factor Analysis for marketing orientation quality

\begin{tabular}{|l|c|c|c|}
\hline $\begin{array}{l}\text { Statement: My bank marketing } \\
\text { orientation }\end{array}$ & \multicolumn{2}{|c|}{ Communalities } & Component \\
\cline { 2 - 3 } & Initial & Extraction & Matrix \\
\hline $\begin{array}{l}\text { MOQ4 comprises an intelligence } \\
\text { collection }\end{array}$ & 1 & .852 & .923 \\
\hline $\begin{array}{l}\text { MOQ5 comprises an intelligence } \\
\text { collection. }\end{array}$ & 1 & .846 & .920 \\
\hline $\begin{array}{l}\text { MOQ6 comprises response to } \\
\text { intelligence }\end{array}$ & 1 & .836 & .914 \\
\hline $\begin{array}{l}\text { MOQ3 comprises inter-functional } \\
\text { coordination }\end{array}$ & 1 & .710 & .843 \\
\hline $\begin{array}{l}\text { MOQ2 comprises competitor } \\
\text { orientation. }\end{array}$ & 1 & .673 & .820 \\
\hline $\begin{array}{l}\text { MOQ1comprises customer } \\
\text { orientation }\end{array}$ & 1 & .508 & .713 \\
\hline Kaiser-Meyer-Olkin Measure of Sampling Adequacy & .862 \\
\hline Bartlett's Test of Sphericity Approx. Chi-Square & 675.482 \\
\hline df & 15 \\
\hline Sig & .000 \\
\hline Initial Eiganvalues & 4.425 \\
\hline Total Variance Explained\% & $73.76 \%$ \\
\hline
\end{tabular}

Note: Variables loaded significantly on factor with Coefficient of at least $0.5, \mathrm{~N}=117,{ }^{* *} \mathrm{p}<0.01$

\section{Factor Analysis for brand equity:}

Factor analysis is also done on ten statements, which were used to measure Brand Equity Management (BEM). Table (6) shows the summary of results of factor analysis on brand equity drivers. In the first run of factor analysis, statement BEM10 was found to have communalities less than 0.50 , and it is dropped. Also to provide a simple structure column for interpretation, the factors were subjected to Varimax rotation. All the remaining items had more than recommended value of at least 0.50 in MSA with KMO value of 0.936 and Bartlett's test of sphericity is significant $(1233.842, \mathrm{p}<.01)$. Finally, all assumptions were satisfactorily fulfilled, Table (6) also shows that the statements for brand equity loaded on one factor with Eigen values exceeding 1.0. This factor explains $78.43 \%$ of the variance in the data, and the factor loading of brand equity drivers items ranged from 0.787 to 0.943 . Thus, the statements are appropriate for factor analysis, and this study found that a brand equity driver consists of nine items.

Table 6: Factor Analysis for brand equity

\begin{tabular}{|l|c|c|c|}
\hline Statements: My bank & \multicolumn{2}{|c|}{ Communalities } & Compone \\
\cline { 2 - 4 } & Initial & Extraction & nt Matrix \\
\hline $\begin{array}{l}\text { BEM4 ensures that our } \\
\text { communications strategies } \\
\text { effectively remind existing } \\
\text { customers to return or tell others. }\end{array}$ & 1 & .889 & .943 \\
\hline $\begin{array}{l}\text { BEM2 utilizes marketing research to } \\
\text { determine the appropriate creative } \\
\text { approach (the right message is } \\
\text { communicated in the right way). }\end{array}$ & 1 & .881 & .939 \\
\hline $\begin{array}{l}\text { BEM3 measures the extent to which } \\
\text { it is attracting new customers. }\end{array}$ & 1 & .869 & .932 \\
\hline BEM5 develops communications & 1 & .856 & .925 \\
\hline
\end{tabular}




\begin{tabular}{|l|c|c|c|}
\hline $\begin{array}{l}\text { strategies that build emotional ties } \\
\text { with our customers. }\end{array}$ & & & \\
\hline $\begin{array}{l}\text { BEM1 determines the right mix of } \\
\text { communications strategies to } \\
\text { effectively reach the bank's current } \\
\text { and potential customers. }\end{array}$ & 1 & .802 & .895 \\
\hline $\begin{array}{l}\text { BEM9 examine our community } \\
\text { record, environmental record, and } \\
\text { hiring and work practices to } \\
\text { improve where necessary. }\end{array}$ & 1 & .752 & .867 \\
\hline $\begin{array}{l}\text { BEM6 conducts research to examine } \\
\text { the extent to which ours } \\
\text { communications are watched, read, } \\
\text { listened to, experienced, and acted } \\
\text { upon by the customer and by the } \\
\text { bank. }\end{array}$ & 1 & .731 & .855 \\
\hline $\begin{array}{l}\text { BEM7 determines our customer's } \\
\text { perceptions of our bank's ethics. }\end{array}$ & 1 & .659 & .812 \\
\hline $\begin{array}{l}\text { BEM8 develops a data privacy } \\
\text { policy for our organization. } \\
\text { Communicate it to our customers, } \\
\text { employees, and stakeholders. }\end{array}$ & 1 & .619 & .787 \\
\hline Kaiser-Meyer-Olkin Measure of Sampling Adequacy & .936 \\
\hline Bartlett's Test of Sphericity Approx. Chi-Square & 1233.842 \\
\hline df & 36 \\
\hline Sig & .000 \\
\hline Initial Eiganvalues & 7.059 \\
\hline Total Variance Explained\% & $78.43 \%$ \\
\hline
\end{tabular}

Note: Variables loaded significantly on factor with Coefficient of at least $0.5, \mathrm{~N}=117,{ }^{* *} \mathrm{p}<0.01$

\section{Reliability Statistics and Descriptive Statistics}

Reliability is an assessment of the degree of consistency between multiple measurements of variables (Hair et. al., 2010). To test reliability, this study used Cronbach's alpha as a diagnostic measure, which assesses the consistency of entire scale, since being the most widely used measure (Sharma, 2000). According to (Hair etal., 2010), "the lower limit for Cronbach's alpha is 0.70". The results of the reliability analysis summarized in Table (7) confirms that all the scales display a satisfactory level of reliability (Cronbach's alpha exceeded the minimum value of 0.70). Therefore, it can be ended that the measures have an acceptable level of reliability. Table (7) shows that the reliability coefficient for system quality was 88.2, information quality was 93.8, support service quality was 84.6. Moreover, for the marketing orientation quality was 92.8 . Also, the reliability of brand equity was 96.5. Thus, the model was reliable for the sample and above the acceptable level.

On the other hand, the Table (7) shows the means and standard deviations of the four components of marketing information system quality and brand equity. The table also reveals that the Sudanese banking sector emphasized more on system quality (mean=3.9160, standard deviation $=0.83344$ ), followed by information quality (mean $=3.9100$, standard deviation $=0.80788$ ), then support service quality(mean $=3.7962$, standard deviation=0.76539), and finally is the marketing orientation quality $($ mean $=3.7095$, standard deviation $=0.81845$ ). Therefore, those four dimensions were achieved an average score equal (3.8329). Given that the model scale used a 5-point scale (1=strongly disagree, $5=$ strongly agree), it can be concluded that Sudanese banking industry banks are highly of system quality and information quality above the average mean. On the other hand brand equity scores (mean=3.6280, standard deviation $=0.88227$ ). Also all the means values above the assumed mean that equals 3.0000 .

Table 7: Reliability Statistics and Descriptive Statistics ( $\mathrm{N}=117)$

\begin{tabular}{|l|c|c|c|c|}
\hline \multirow{2}{*}{ Variables } & \multicolumn{2}{|c|}{$\begin{array}{c}\text { Reliability } \\
\text { Statistics }\end{array}$} & \multicolumn{2}{c|}{$\begin{array}{c}\text { Descriptive } \\
\text { Statistics }\end{array}$} \\
\cline { 2 - 5 } & $\begin{array}{c}\text { Cronbach } \\
\text { s Alpha }\end{array}$ & $\begin{array}{c}\text { N of } \\
\text { Items }\end{array}$ & Mean & $\begin{array}{c}\text { Std. } \\
\text { Deviation }\end{array}$ \\
\hline System Quality & .882 & 4 & 3.9160 & .83344 \\
\hline Information Quality & .938 & 7 & 3.9100 & .80877 \\
\hline Support Service Quality & .846 & 5 & 3.7962 & .76539 \\
\hline $\begin{array}{l}\text { Marketing orientation } \\
\text { Quality }\end{array}$ & .928 & 6 & 3.7095 & .81845 \\
\hline Brand Equity & .965 & 9 & 3.6280 & .88227 \\
\hline
\end{tabular}

\section{Correlation Analysis}

Table (8) presents the results of the intercorrelation between the model variables. The correlation analysis was conducted to see the initial picture of the interrelationships between the study model variables. Table (8) represents the correlation matrix for the constructs operationalized in this study. These bivariate correlations allow for preliminary inspection and information regarding hypothesized relationships. Besides that, correlation matrix gives information regarding test for the presence of multicollinearity. The table shows that multicollinearity is not a significant problem because no correlation is reaching 0.8 and more.

Table (8) shows that system quality, information quality, marketing orientation quality, and support service quality are positively and significantly correlated with brand equity $(\mathrm{r}=.522, \mathrm{p}$-value $<0.01),(\mathrm{r}=.625$, $\mathrm{p}$-value $<0.01),(\mathrm{r}=.671$, $\mathrm{p}$-value $<0.01),(\mathrm{r}=.663$, $\mathrm{p}$-value $<0.01)$ respectively. This table provides a strong indication of association, to undertake a complete examination of the proposed relationships, and to evaluate whether such associations are direct or indirect, multiple regression test is conducted. The following section is the hypotheses testing.

Table 8: Pearson's correlation among the model variables

\begin{tabular}{|l|c|c|c|c|c|}
\hline Variables & $\begin{array}{c}\text { System } \\
\text { Quality }\end{array}$ & $\begin{array}{c}\text { Information } \\
\text { Quality }\end{array}$ & $\begin{array}{c}\text { Support } \\
\text { Service } \\
\text { Quality }\end{array}$ & $\begin{array}{c}\text { Marketing } \\
\text { Orientation } \\
\text { Quality }\end{array}$ & $\begin{array}{c}\text { Brand } \\
\text { Equity }\end{array}$ \\
\hline System Quality & 1 & & & & \\
\hline $\begin{array}{l}\text { Information } \\
\text { Quality }\end{array}$ & $.789^{* *}$ & 1 & & & \\
\hline $\begin{array}{l}\text { Support Service } \\
\text { Quality }\end{array}$ & $.527^{* *}$ & $.621^{* *}$ & 1 & & \\
\hline $\begin{array}{l}\text { Marketing } \\
\text { Orientation Quality }\end{array}$ & $.580^{* *}$ & $.601^{* *}$ & $.696^{* *}$ & 1 & \\
\hline Brand Equity & $.522^{* *}$ & $.625^{* *}$ & $.671^{* *}$ & $.663^{* *}$ & 1 \\
\hline
\end{tabular}

Notes: Level of significant: ${ }^{* *} \mathrm{p}<0.01, \mathrm{~N}=117$. 


\section{The Relationship between Marketing Information System quality and Brand Equity}

Table (9) shows the results of the multiple regression equation testing the impact of the marketing information system variables on brand equity. The marketing information system variables explained $56 \%$ of the variance in brand equity. However, the result shows that the model is significant. In addition, the results showed that three out of four components of marketing information system are positive significantly influenced brand equity. The results showed that the hypothesis was supported, i.e., there is a positive relationship between marketing information system and brand equity. The results also showed that marketing orientation quality has the most significant impact on brand equity $(B=0.310$, $\mathrm{p}<0.01)$, followed by information quality $(B=0.306$, $\mathrm{p}<0.05)$, and support service quality $(\Omega=0.296, p<0.01)$. On the other hand, the results showed that system quality has negative insignificant impact on brand equity $(B=-0.062$, $\mathrm{p}>0.10$ ). Finally, these results give support to hypotheses H2 (Information quality and brand equity),H3 (Support service quality and brand equity), andH4 (Marketing orientation quality and brand equity). Therefore, these results ensure that marketing information system implementation does lead to building power brand equity.

Table 9: The multiple regression for the relationships between marketing information system quality and brand equity

\begin{tabular}{|l|c|r|}
\hline Model Variables & DV (Brand Equity) & \multirow{2}{*}{ Sig } \\
\cline { 1 - 2 } IV(marketing information system quality): & Std. Beta & \\
\hline Marketing System Quality & -.062 & .571 \\
\hline Marketing Information Quality & $.306^{*}$ & .010 \\
\hline Marketing Support Service Quality & $.296^{* *}$ & .002 \\
\hline Marketing orientation Quality & $.310^{* *}$ & .001 \\
\hline F value $=35.866^{* *}$ & \\
\hline $\mathrm{R}^{2}=.562$ & \\
\hline Adjusted $\mathrm{R}^{2}=.546$ & \\
\hline $\mathrm{R}^{2}$ change $=.562$ & \\
\hline F change $=35.866^{* *}$ & \\
\hline
\end{tabular}

Note: Level of significant: ${ }^{*} \mathrm{p}<0.05,{ }^{* *} \mathrm{p}<0.01$

\section{Discussion}

Marketing information system had been hypothesized to have a positive influence on brand equity. The findings of this study showed that marketing information quality, marketing support service quality, and marketing orientation quality are significantly and positively related to brand equity. However, marketing system quality points out an insignificant negative relationship with brand equity. Therefore, many researchers argued the reasons for that can be "many US companies reported to be not fully exploiting the latest information technologies to create competitive advantages, and many marketing managers are not satisfied with their marketing information system" Li, 1997; Abdel Hafiez and Mohamed, 2014).
Likewise Maguire and Jiao, (2008), reports of the failure of information systems and technology projects were driven by several factors, including poor project management, and the lack of understanding of how systems can negatively affect organizations and customer relationships. In evaluating the system quality, most researchers' measures consider engineeringoriented performance characteristics (Mahmood, 1987).

In general, the findings of this study, provide support for the affirmation made by scholars (e.g. Kim and Lennon, 2010) who argued that the effectiveness of marketing information system is set up to compose both internal and external components. More particularly, marketing information system could contribute to the proper identification of consumer needs and, as an outcome, help to cultivate a more satisfied and loyal customer (Kalliopi and Christos, 2010).

The findings of the research brought out that support service quality has a significant influence on brand equity. This outcome is concur with (Jamali, 2007) who set up that "internal performance needs to be enhanced as it is a reflection of actual service quality, to customers' satisfaction with service quality". Also, Gounaris et al., (2003) considered service quality as an essential factor that allows an organization to differentiate itself from competitors and gain a sustainable competitive advantage. The findings show that the marketing orientation has a positively significant influence on brand equity. The findings agree with previous research, that set up "the adopting of the market orientation facilitates each company's collection, processing, and diffusion of information, then resulting in the company's knowledge of the customers' needs" (Kohli and Jaworski, 1990; Narver and Slater, 1990;Kalliopi and Christos, 2010).

\section{IMPLICATIONS OF THE STUDY}

The present research has supported the current knowledge on business branding of marketing information system within the banking sector. The first theoretical contribution focuses on the positive relationship between marketing information system and brand equity drivers. The second theoretical contribution of this research adds to the resource-based view approach. Particularly, the findings of this research showed that marketing information system is a resource, that it is the substantial determinant of brand equity.

The third theoretical contribution of this study showed that the four components of marketing information system do not equally contribute to brand equity drivers. While three components of marketing information system (information quality, support service quality, and marketing orientation) have significant positive influence on brand equity, system quality had the negative insignificant impact on brand equity. 
For managerial implication, this study contributes towards management practice. Concerning the marketing information system gains benefits from information taken out these findings to strange brand equity decisions or to know essential blocks to build brand resonance, and reputation.

\section{LIMITATIONS AND SUGGESTIONS}

The findings of this study must been interpreted with caution because of some certain limitations. First, while the study is done in Sudanese Banking Sector is limits its generalizability to other sectors such as the manufacture sector. Finally, this study investigates the relationship between marketing information system and brand equity drivers across the banking sector.

This study shows an attempt to build and test a theoretical framework of marketing information system and brand equity. Based on the limitations mentioned above, this study provides some proposals for the future research as follows: First, future studies can replicate this study using larger sample, and different sectors or countries.

The results showed an insignificant negative relationship between marketing system quality and brand equity. This result suggests that the relationship may need moderator variables or new items of measure of system quality. Further study is needed to test such relationships. Finally, the $\mathrm{R}^{2}$ value in this study is 0.56 for the direct relationships between marketing information system and brand equity. So, there are many factors not just marketing information system that impact brand equity. One imaginable factor is marketing strategies such as competitor oriented strategies. Further researches should introduce such factors.

\section{Conclusions}

This study is an investigation to know the banking sector brand equity drivers. On the other hand, this study tried to investigate the relationship between marketing information system quality and brand equity management, expressing the role that key components of marketing information system quality play in that relationships. The current study is run among 31 banks affiliated with the Central Bank of Sudan. This study provided empirical evidence that marketing information system quality can lead Sudanese banks to sustainable competitive advantage in terms of loyalty and brand equity.

\section{REFERENCES}

Abdel Hafiez Ali Hasaballah and Mohamed Salih Yousif Ali. (2014), "The Relationship between information System Quality and Customer Equity Management in Service Sector", Asia Pacific Journal of Marketing \& Management Review Vol.3 (3), MARCH, pp. 24-37.

Alshawi, S., Irani, Z. and Baldwin, L. (2003), "Benchmarking information technology investment and benefits extraction", Benchmarking: An International Journal, Vol. 10 No. 4, pp. 414-23.
Bailey, J. E. and Pearson, S. W. (1983), "Development of a tool for measuring and analyzing computer user satisfaction", Management Science, Vol. 29, No. 5, pp. 530-45.

Berry, L.L. (2000), "Cultivating service brand equity", Journal of the Academy of Marketing Science, Vol. 28 No. 1, pp. 128-37.

DeLone, W. H. and McLean, E. R. (2004), "Measuring ecommerce success: applying the information systems success model", International Journal of Electronic Commerce, Vol. 9 No. 1, pp. 31-47.

Ennew, C.T., and Binks, M.R. (1996), the impact of service quality and service characteristics on customer retention: small businesses and banks in the UK. British Journal of Management, seven issue3, 219-30.

Gounaris, S. and Venetis, K. (2002), "Trust in industrial service relationships: behavioral consequences, antecedents and the moderating effect of the duration of the relationship", Journal of Services Marketing, Vol. 16 No. 7, pp. 636-55.

Hair, J.F., Anderson, R. E., Tatham, R.L. and Black, W.C. (2010), Multivariate Data Analysis (7th Ed.). Prentice Hall Inc., Upper Saddle River, NJ.

Hanssens, D.M., Thorpe, D. and Finkbeiner, C. (2008), "Marketing When Customer Equity Matters", Harvard Business Review, pp. 117-23.

Huang, S.M., Ou, C.S., Chen, C.M. and Lin, B. (2006), "An empirical study of relationship between IT investment and firm performance: a resource-based perspective", European Journal of Operational Research, Vol. 173, pp. 984-99.

Jamali, D. (2007),"A study of customer satisfaction in the context of a public private", January-February, pp. 65-79.

Jaworski, B. J. and Kohli, A. K. (1993), “Market orientation: antecedents and consequences", Journal of Marketing, Vol. 57, No. 3, pp. 53-70.

Kalliopi C. Chatzipanagiotou, Christos D. Coritos. (2010), “A suggested typology of Greek upscale hotels based on their MrkIS: Implications for hotels' overall effectiveness", European Journal of Marketing Vol. 44 No. 11/12, pp. 1576-1611.

Keller, K.L. (1993), “Conceptualizing, measuring, and managing customer-based brand equity", Journal of Marketing, Vol. 57, January, pp. 1-22.

Kim, J. and Lennon, S. J. (2010), “Information available on a web site: effects on consumers' shopping outcomes", Journal of Fashion Marketing and ManagementVol. 14 No. 2, pp. 247-62.

Kohli, A. K. and Jaworski, B. J. (1990), "Market orientation: the construct, research propositions, and managerial implications", Journal of Marketing, Vol. 54, No. 2, pp. 1-18.

Kumar.V, Girish Ramani, and Timothy Bohling (2004), "Customer lifetime value approaches and best practice applications", Journal of Interactive Marketing,Vol.18 No. 3, pp 60-72.

Lemon, K. N., Rust, R.T., and ZeithamI, V. A. (2001),"What drives customer equity? Marketing Management", Vol. 10, No. 1, pp. 21- 25.

Li, E. (1997),“Marketing information systems in small companies", Information Resources Management Journal, Vol. 10 No. 1, pp. 27-35.

Maguire, S., and Ojiako, U. (2008),"Market-led systems development: when customers become users", Industrial Management and Data Systems, Vol. 108 No. 2, pp. 173-90.

Mahmood, Mo.A. (1987), "Systems development methods- a comparative investigation", MIS Quarterly, Vol. 11 No. 3, pp. 293-311.

Marconi, J. (1993), Beyond Branding: How Savvy Marketers Build Brand Equity to Create Products and Open New Markets, Probus Publishing Company, Chicago, IL. 
Marshall, K.P. and La Motte, S.W. (1992), "Marketing information systems: a marriage of systems analysis and marketing management", Journal of Applied Business Research, Vol. 8 No. 3, pp. 61-73.

Narver, J. C. and Slater, S. F. (1990), The effect of a market orientation on business profitability, Journal of Marketing, Vol. 54, No. 4, pp. 20-35.

Petrison, L.A. and Wang, P. (1993), "From relationships to relationship marketing: applying database technology to public relations", Public Relations Review, Vol. 19 No. 3, pp. 235-45.

Rigby, D. K., F. F. Reichheld, and P. Schefter (2002),"Avoid the four perils of CRM",Harvard Business Review, February.

Rust, R. T, Zeithaml, V. A., and Lemon, K. N. (2000), Driving customer equity: How customer lifetime value is reshaping corporate strategy, New York: The Free Press.

Rust, R. T, Zeithaml, V. A., and Lemon, K. N. (2004), “Customercentered brand management", Harvard Business Review, Vol. 82, No. 9, pp. 110-18.
Saaksjarvi, M.V.T. and Talvinen, J.M., (1993),Integration and effectiveness of marketing, San Francisco, CA.

Sharma, S. (2000), "Managerial interpretation and organizational context as predictors of corporate choice of environmental strategy", The Academy of Management Journal, Vol. 43, No. 4, pp. 681-97.

Wierenga, B., Van Bruggen, G. H. and Staelin, R. (1999), "The success of marketing management support systems", Marketing Science, Vol. 18, No. 3, pp. 196-207

Yoo, B. and Donthu, N. (2001), "Developing and validating a multidimensional consumer-based brand equity scale", Journal of Business Research, Vol. 52, pp. 1-14.

Zeithaml, V. A., Berry, L. L. and Parasuraman, A. (1996), "The behavioral consequences of service quality", Journal of Marketing, Vol. 60 No. 2, pp. 31-46.

$--0-$ 